\section{Kompetente Sonografie beendet diagnostische Irrfahrt - eine nicht alltägliche Aszitesuntersuchung}

\section{Einführung}

$\nabla$

Die Differenzialdiagnose (DD) einer freien abdominellen Flüssigkeit ist vielfaltig und kann durchaus anspruchsvoll sein. Häufigste Ursachen sind portale Hypertension (Leberzirrhose), Rechtsherzinsuffizienz, Peritonealkarzinose oder Pankreatitis. Die Sonografie kann nicht nur am sensitivsten kleine Mengen von Aszites erkennen, sondern auch in der DD einen entscheidenden Beitrag leisten, z. B. durch die Erkennung der Grunderkrankung (Zirrhose, Tumorleiden u. A.). Eine seltene Ursache einer abdominellen Flüssigkeitsansammlung stellt der Urineinstrom durch eine Leckage des Harnwegssystems dar. Bei geringem Flow ist die Klinik blande und kann zu Verwirrungen führen. Dies unterstreicht der nachfolgende Fall einer jungen Frau mehrere Wochen nach gynäkologischer Operation.

\section{Fallbeschreibung}

$\checkmark$

Anamnese, Krankheitsverlauf und Diagnostik

Eine 45-jährige, bisher gesunde und sportliche Frau (FitnessTrainerin) wurde im Abstand von 18 Monaten wegen Uterus myomatosus hysterektomiert und linksseitig bei serösem Kystom ovarektomiert. 3 Wochen nach letzterem Eingriff musste eine laparoskopische Adhasiolyse bei Bridenileus des Dünndarmes erfolgen. Auffällig waren dabei reichlich klarer Aszites sowie diskrete Fibrinbeläge im Bereich der Ovarektomie. Der Aszites war klinisch bis zu diesem Zeitpunkt nicht relevant. Es wurde eine entzündliche Genese des Aszites im Zusammenhang mit dem Ileus vermutet. Eine Laboruntersuchung wurde nicht veranlasst. Nach der Entlassung bemerkte die Patientin eine kontinuierliche langsame Zunahme des Bauchumfanges, sodass sie nicht in der Lage war, ihre berufliche Tätigkeit wieder aufzunehmen. 6 Wochen später erfolgte deshalb die Wiederaufnahme in der Chirurgischen Klinik. Sonografie ( Abb. 1, 2) und Computertomo-

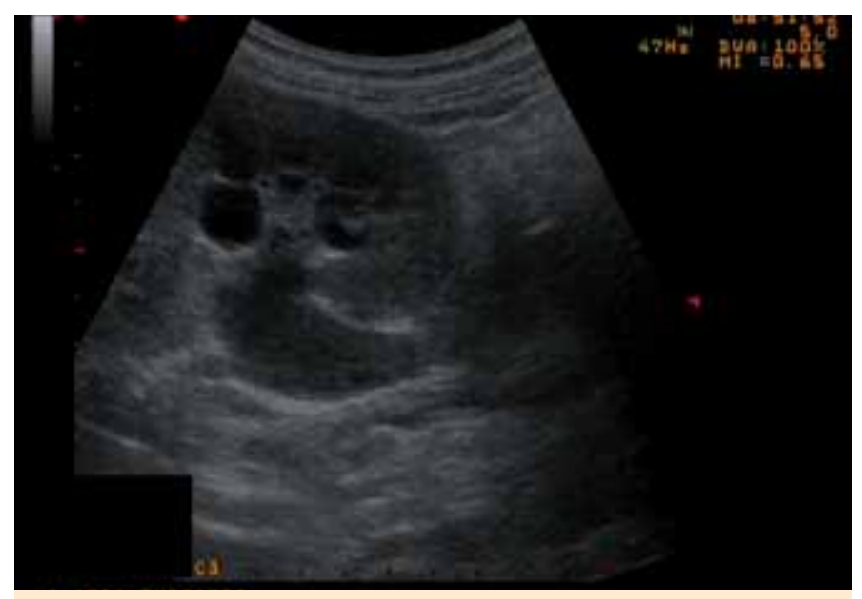

Abb. 1 Linke Niere mit Harnstauung und Darstellung des Ureterabganges. Fig. 1 Left kidney with urinary obstruction and the leaving ureter.

\section{Competent Sonography Brings a Diagnostic Odyssey to an End - a Case of Seldom Genesis of Ascites}

\author{
Introduction
}

$\nabla$

The differential diagnosis (DD) of free abdominal fluid is complicated and can be challenging. The most common causes are portal hypertension (liver cirrhosis), right heart insufficiency, peritoneal carcinomatosis, and pancreatitis. Sonography provides the most sensitive detection of small ascites and also contributes greatly to DD, e.g. by identifying underlying diseases (cirrhosis, neoplastic disease, etc.). A rare cause of abdominal fluid collection is an inflow of urine through a leak in the urinary tract. In the case of a minimal flow, the symptoms are mild and can result in confusion. This is illustrated by the following case of a young woman several weeks after gynecological surgery.

\section{Case description \\ Anamnesis, disease course, and diagnostics}

Over the course of 18 months, a 45 year-old, previously healthy and athletic woman (fitness trainer) underwent a hysterectomy due to uterine myomatosis and an ovariectomy on the left side due to serous cystoma. 3 weeks after the last operation, a laparoscopic adhesiotomy had to be performed due to adhesive strangulation of the small intestine. A clear ascites and discrete fibrin deposits in the region of the ovariectomy were noticeable. The ascites was not clinically relevant until this point in time. An inflammatory genesis of the ascites in connection with the ileus was suspected. A laboratory examination was not ordered.

After being released, the patient noticed a continuous slow increase in abdominal girth which prevented her from returning to work. She was consequently readmitted to the surgical clinic 6 weeks later. Sonography ( Fig. 1, 2) and computed tomography showed a massive ascites in all 4 quadrants and hydronephrosis

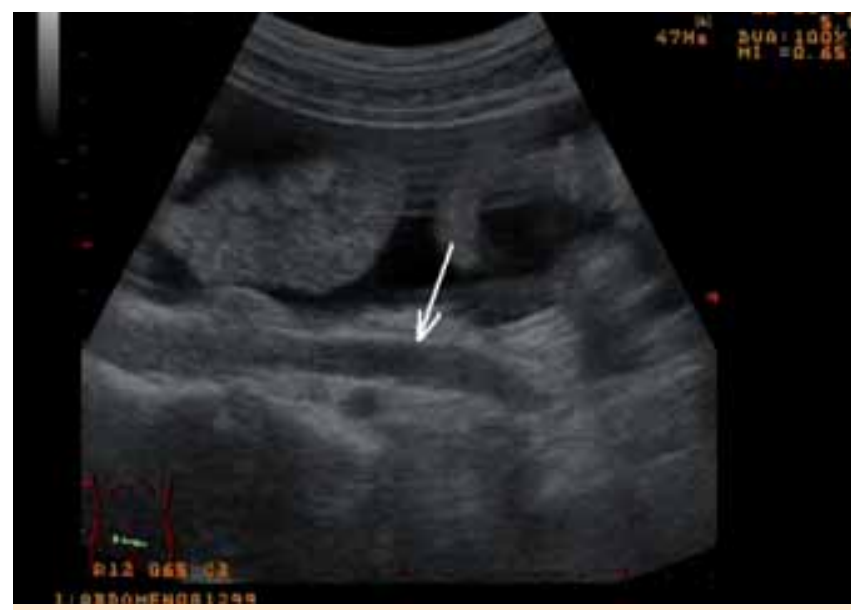

Abb. 2 Dünndarmschlingen im Aszites und Darstellung des erweiterten Ureters links im Longitudinalschnitt.

Fig. 2 Small bowel loops in ascites and dilated ureter in longitudinal section. 
grafie zeigten einen massiven Aszites in allen 4 Quadranten und eine Harnstauungsniere links. Die Ursache des Aszites lies sich sonografisch nicht klären. Die Serumlabordiagnostik war einschließlich Kreatinin und Harnstoff normwertig. Die diagnostische Aszitespunktion zeigte unauffällige mikrobiologische und zytologische Befunde. Auch die Laborchemie mit Amylase, Cholesterol, Albumin, Protein und Bilirubin lag im Normbereich. Der Kreatininwert im Punktat war mit $283 \mu \mathrm{mol} / \mathrm{l}$ erhöht, der Harnstoff mit 7,54 mmol/l im Grenzbereich; dies fand allerdings keine besondere Beachtung.

Die hinzugezogenen Fachvertreter von Gynäkologie und Innerer Medizin konnten zunächst keine Ursache des Aszites erkennen. Internistischerseits wurde eine Behandlung mit Diuretika empfohlen und die Übernahme der Patientin vereinbart. Die internistische Sonografie der Patientin zeigte außer dem Aszites keine Auffälligkeiten im Organstatus. Die Labordiagnostik war bis auf ein leicht erhöhtes Kreatinin wiederum normwertig. Die Sonografie bestätigte die Vorbefunde zunächst ohne Hinweis auf die Aszitesgenese. Die diagnostische Aszitespunktion erbrachte wiederum unauffällige mikrobiologische, zytologische und laborchemische Befunde. Ein Kreatinin wurde nicht bestimmt.

\section{Therapie und weiterer Verlauf}

Unter der fortlaufenden diuretischen Behandlung kam es zu einer leichten Gewichtsreduktion (2 kg). Die Patientin wurde bei Aufrechterhaltung der bisherigen Arbeitsdiagnose eines entzündlichen Aszites unter fortlaufender diuretischer Therapie mit einem Vorstellungstermin beim Urologen zur Abklärung der Harnstauungsniere in die ambulante Betreuung entlassen. 2 Wochen später erfolgte die stationare Aufnahme in der Urologischen Klinik Beabsichtigt war eine linksseitige (diagnostische) Nephrostomie. Unmittelbar präinterventionell wurde die Patientin zur ultraschallgestützten Aszitesentlastungspunktion vorgestellt, denn aufgrund des ausgeprägten Aszites war ihr die für den Eingriff notwendige Bauchlagerung auf dem OP-Tisch nicht möglich. Aus diesem Anlass erfolgte nochmals eine gründliche und qualifizierte sonografischen Exploration (DEGUM 2). Hierbei fiel im kleinen Becken unterhalb des Ligamentum latum ein Jet-Phänomen (Abb. 3, 4) auf, das sowohl im B- Bild wie auch im Power- Mode

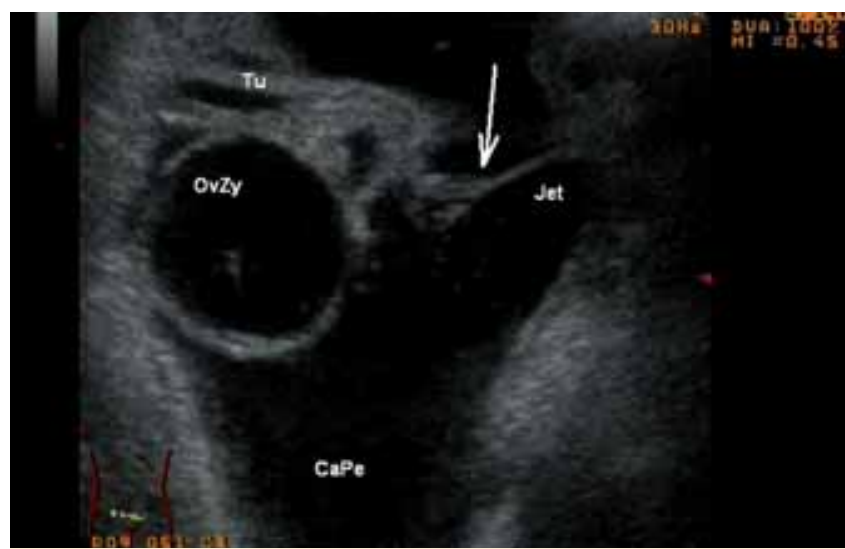

Abb. 3 Eindrucksvolles Jet-Phänomen durch Ureterleckage im B-Bild; Darstellung kleines Becken mit Aszites, Ovarialzyste; Schnitt Unterbauch suprapubisch; Urin-Jet mit Pfeil markiert; OvZy: Ovarialzyste; CaPe: Cavum peritonei; Tu: Tuba uterina.

Fig. 3 Impressive jet-phenomenon caused by uereter leakage in b-mode; view in the small pelvis with ascites and ovarian cyst, marked by arrow. on the left side. The cause of the ascites was not able to be clarified sonographically. According to the serum laboratory results, the values including the creatinine and urea levels were normal. Diagnostic ascites puncture yielded normal microbiological and cytological findings. The amylase, cholesterol, albumin, protein, and bilirubin values were also in the normal range. The creatinine level in the aspirate was elevated at a value of $283 \mathrm{~mol} / \mathrm{l}$ and the urea level was on the threshold at a value of $7.54 \mathrm{mmol} / \mathrm{l}$. However, this was not given special consideration.

The consulted gynecology and internal medicine experts were initially not able to detect a reason for the ascites. Treatment with a diuretic was recommended and transfer of the patient to the internal medicine department was agreed upon. The sonography of the patient performed in the internal medicine department did not show any abnormalities other than the ascites. The lab values were normal except for the slightly elevated creatinine level. Sonography initially confirmed the preliminary findings without providing an indication of the genesis of the ascites. The diagnostic ascites puncture did not yield any abnormal microbiological, cytological, or laboratory findings. Creatinine was not identified.

\section{Treatment and further course}

A slight weight loss (2 kg) was observed during continued diuretic treatment. The current working diagnosis of an inflammatory ascites was maintained and the patient was released for outpatient care with continuing diuretic treatment and an appointment with a urologist to clarify the hydronephrosis. 2 weeks later the patient was admitted to the urological clinic. A (diagnostic) nephrostomy on the left side was planned. Immediately prior to the intervention, the patient was presented for ultrasound-supported ascites puncture because the prone position on the operating table necessary for the operation was not possible due to the pronounced ascites. A thorough and skilled sonographic exploration was consequently performed again (DEGUM 2). A jet phenomenon ( Fig. 3, 4) under the broad ligament in the lesser pelvis was noticed, was clearly visible in both the B-image and in the power mode, and demonstrated an inflow of fluid into the free abdominal cavity on the left cranial to the bladder. This could

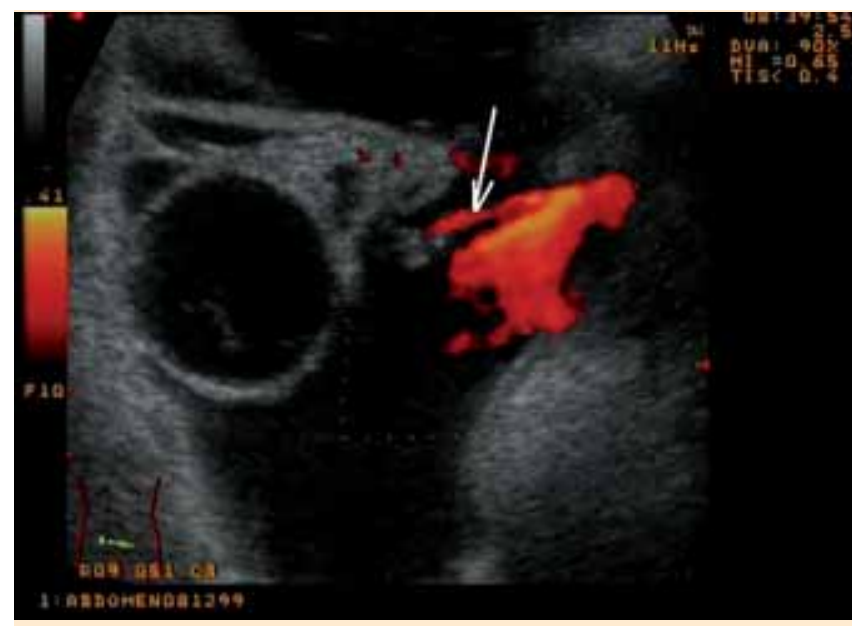

Abb. 4 Jet-Phänomen bei Urin-Leckage aus linkem Ureter ins kleine Becken; Darstellung im Power Doppler.

Fig. 4 Jet phenomenon caused by urinary leakage from the left ureter into the small pelvis; demonstration with power doppler. 
eindrucksvoll imponierte und einen Flüssigkeitseinstrom in die freie Bauchhöhle links kranial der Harnblase demonstrierte. Hierbei konnte es sich bei gleichzeitiger Harnabflussstörung links und dem bekannten Z. n. operativem Eingriff im Bereich des linken Ovars nur um eine Ureterleckage handeln.

Nach Aszitesentlastung wurde nunmehr eine Nephrostomie links angelegt, die einen Kontrastmittelstopp im distalen Ureter zeigte. Auch die anschliesende diagnostische Ureterozystoskopie mit retrograder Harnleiterdarstellung bestätigte die distale Ureterstriktur und zeigte ein kleines Kontrastmittel-Paravasat zum Beweis der Ureterleckage.

Es erfolgte nunmehr die operative Revision durch eine Ureterozystoneostomie. Der Aszites war bereits unmittelbar postoperativ komplett beseitigt und die Patientin konnte nach 10 Tagen „geheilt“ die Klinik verlassen.

\section{Diskussion}

$\nabla$

Aszites infolge einer iatrogenen Ureterleckage wird in der Inneren Medizin als mögliche DD freier abdomineller Flüssigkeiten nicht aufgeführt. Dagegen wird sie in der gynäkologischen, urologischen und chirurgischen Literatur als typische, aber seltene Komplikation laparoskopischer Eingriffe beschrieben (CholkeriSingh A et al. J Minim Invasive Gynecol 2007; 14: 356 - 361; Gao J et al. Chin Med Sci J2007; 22: 13 - 16; Milingos S et al. J Minim Invasive Gynecol 2007; 14: 43 - 48). Für die laparoskopische Hysterektomie und Ovarektomie wird eine Inzidenz zwischen 0,4 und 3\%, für die laparoskopischer Kolektomie eine von 2\% (Powsner R et al. Nucl Med 1997; 22: 523 - 525) angegeben. Der klinische Befund wird von der Größe der Leckage bestimmt. Er ist in der Regel in den ersten postoperativen Tagen durch Schmerzen, Aszites bzw. Urinaskos sowie den Nachweis einer Harntransportstörung bzw. Ureterstenose auf der betroffenen Seite gekennzeichnet und führt letztlich zur Diagnose.

Im vorgestellten Fall lag nur ein relativ kleines Ureterleck vor, das lediglich einen blanden und sehr protrahierten klinischen Verlauf bewirkte. Dies führte dazu, dass an den vorliegenden kausalen Zusammenhang zwischen der vorangegangenen Operation im kleinen Becken und der Aszitesentstehung nicht gedacht wurde. Die Sonografie ist sehr gut geeignet zur Beurteilung der ableitenden Harnwege (Hege-Blank U et al. Ultraschall in Med 1987; 8: 126 - 130); der direkte sonografische Nachweis einer Leckage ist jedoch eine Rarität und gelang eher zufällig bei der Nachuntersuchung durch einen qualifizierten Sonografeur und brachte die definitive Diagnose.

Ein Jet-Phänomen im B-Bild wird beim Einstrom von Flüssigkeit in andere mit hoher Geschwindigkeit beobachtet und entsteht durch die Turbulenzen des Flüssigkeitsstromes. Ein natürliches, aber typisches Beispiel ist das Jet-Phänomen in der Harnblase beim Urineinstrom aus den distalen Ureteren. Das Phänomen wird z. B. auch beim Bluteinstrom in (Pseudo-)Aneurysmata beobachtet. have been simple ureter leakage given the simultaneous urinary obstruction and the known surgical intervention in the area of the left ovary.

After ascites drainage, a nephrostomy was created on the left and showed contrast agent stoppage in the distal ureter. The subsequent diagnostic ureterocystoscopy with retrograde ureter visualization confirmed the distal ureter stenosis and showed minor contrast agent paravasation thus verifying ureter leakage.

Surgical revision was then performed by ureteroneocystostomy. The ascites was postoperatively completely eliminated and the "cured" patient was able to leave the clinic after 10 days.

\section{Discussion \\ $\nabla$}

Ascites as the result of iatrogenic ureter leakage is not included as a possible $\mathrm{DD}$ of free abdominal fluid in internal medicine. However, it is described as a characteristic but rare complication of laparoscopic interventions in gynecological, urological, and surgical literature (Cholkeri-Singh A et al. J Minim Invasive Gynecol 2007; 14: 356-361; Gao J et al. Chin Med Sci J2007; 22: 13-16; Milingos S et al. J Minim Invasive Gynecol 2007; 14: 43-48). A rate of incidence between $0.4 \%$ and $3 \%$ is specified for laparoscopic hysterectomy and ovariectomy and a rate of $2 \%$ is indicated for laparoscopic colectomy (Powsner R et al. Nucl Med 1997; 22: 523525 ). The clinical finding is determined by the size of the leakage. It is typically characterized in the first postoperative days by pain, ascites or urinary ascites and evidence of a urinary obstruction or ureter stenosis on the affected side and finally results in a diagnosis.

The present case included a relatively small ureter leak that resulted in a mild and very protracted clinical course. As a result, the causal relationship between the preceding lesser pelvis surgery and formation of the ascites was not taken into consideration. Sonography is very suitable for assessing the efferent urinary tract (Hege-Blank U et al. Ultraschall in Med 1987; 8: 126-130). However, direct sonographic evidence of leakage is a rarity and was only identified coincidentally during re-examination by a qualified sonographer and thus definitively diagnosed.

A jet phenomenon in the B-image is observed when one fluid flows into another with high speed, thus causing turbulence in the flow. A natural and characteristic example of the jet phenomenon in the bladder is seen during urine flow from the distal ureters. The phenomenon is also observed for example during blood inflow into (pseudo) aneurysms.

\section{Conclusion \\ $\nabla$}

Mild symptoms resulted in a diagnostic odyssey to diagnose surgically caused ureter leakage after ovariectomy and adhesiotomy. Differential diagnosis and differential sonography of ascites are multifaceted and should include urinary tract leakage. Skilled sonography impressively showed the distal ureter leakage and the resulting urine ascites. In addition to conventional X-ray (retrograde or invasive antegrade) and scintigraphy, sonography is sui- 


\section{Schlussfolgerung}

Eine blande Klinik führte zu einer diagnostischen Irrfahrt bei einer operativ bedingten Ureterleckage nach Ovarektomie und Adhäsiolyse. Die Differenzialdiagnose und Differenzialsonografie des Aszites ist vielfältig und sollte eine Leckage des Harnwegssystems mit einschließen. Eine qualifizierte Sonografie demonstrierte eindrucksvoll das Bild der distalen Ureterleckage und des dadurch bedingten Urinaskos. Die Sonografie ist neben der konventionellen Röntgendiagnostik (retrograd bzw. invasiv antegrad) und der Szintigrafie durchaus geeignet zur direkten Darstellung. Einmal mehr gilt: „Man sucht nur, was man kennt, und findet nur, was man sucht" (Mauch M et al. Ultraschall in Med 2005; 26: 91 - 93).

- Eine Urinleckage ist eine seltene Ursache eines Aszites (Urinaskos), insbesondere nach urologischer oder gynäkologischer OP

- Die Sonografie ist neben Röntgen-Diagnostik und Szinitgrafie geeignet zur Diagnostik einer Ureterleckage

- Eine qualifizierte klinische Sonografie kann entscheidenden Beitrag leisten und eine Leckage direkt darstellen

Zusätzliche Videos zu diesem Beitrag finden Sie online unter: www.thieme-connect.de/ejournals table for direct visualization. It holds true that "you only look for what you know and only find what you are searching for "(Mauch M et al. Ultraschall in Med 2005; 26: 91-93).

- A very seldom cause of ascites is an ureter leakage, for example developed after an operation in the small pelvis.

- Sonography beside conventional X-ray and szinitgraphy is usefull in direct diagnosis of a ureter leakage.

- The high qualified clinical intended sonography is able to diagnose the ureterleakage directly and to speed up definitve therapy.

'- $\mathbf{A}$ Additional videos are available under www.thiemeconnect.com/ejournals

PD Dr. Dieter Nürnberg

Medizinische Klinik B, Ruppiner Kliniken $\mathrm{GmbH}$

Fehrbelliner Str. 38

16816 Neuruppin

Tel.: ++ 49/33 91/393210

d.nuernberg@ruppiner-kliniken.de 